\title{
Musculoskeletal Findings, Connective and Soft Tissue Findings Completion Status
}

National Cancer Institute

\section{Source}

National Cancer Institute. Musculoskeletal Findings, Connective and Soft Tissue Findings

Completion Status. NCl Thesaurus. Code C162333.

A term used to describe the state or condition of the completeness of the

musculoskeletal system findings data. 